\title{
EFFECT OF COENZYME Q10 AND L-CARNITINE ON GROWTH PERFORMANCE, PHYSICAL AND CHEMICAL BLOOD INDICES, ANTIOXIDANT STATUS AND IMMUNE RESPONSE OF NEWBORN EGYPTIAN BUFFALO CALVES
}

\author{
A.A. Gabr \\ Department of Animal Production, Faculty of Agriculture, Tanta University, 31527, Tanta, Egypt.
}

(Received 31/12/2019, accepted 9/2/2020)

\section{SUMMARY}

I $\mathrm{n}$ an experimental trial lasted 102 days started from the age of 4 days after birth to the weaning age (105 days) conducted to compare the effect of Co-enzyme Q10 (CoQ10) and L-Carnitine (L-Ca)on growth, physical and chemical blood indices immunity, and antioxidant status of newborn Egyptian buffalo calves. Fifteen calves with $36.13 \pm 0.86 \mathrm{Kg}$ initial live body weight (LBW) were allocated into three groups where calves in the first group received no treatment (control group, Ctrl). The calves in the second and the third groups received $40 \mathrm{mg} \mathrm{L}-\mathrm{Ca} / \mathrm{kg} \mathrm{LBW}$ and $10 \mathrm{mg}$ CoQ10/kg LBW, respectively as daily oral doses. Significant differences in weight gain among treatments starting from the age of 60 days where the CoQ10 and L-Ca groups were higher than the control. Blood physical parameters of all experimental animals show no abnormal cases and no alteration in hematological indices among groups were recorded. Meanwhile, blood biochemical contents were varied significantly $(P<0.05)$ among groups, where the control group gave the highest values of glucose, total lipids, total cholesterol, triglyceride, ALT, AST, ALP, T3, and T4compared to the other groups. Moreover, the CoQ10 group exhibited the highest significant $(p<0.05)$ contents of TP and the lowest T3 and T4 values. Furthermore, the highest values of lysozyme and bactericidal activities were recorded in the $\mathrm{CoQ} 10$ group compared to the other groups. Both $\mathrm{CoQ} 10$ and L-Ca groups showed higher superoxide dismutase (SOD) and catalase (CAT) contents than control. In conclusion, CoQ10 or L-Ca supplements improve growth, immunity and antioxidant contents.

Keywords: Egyptian buffalo, co-enzyme Q10, l-carnitine, immune response and oxidative status.

\section{INTRODUCTION}

Intensification as an ideal option for the production of an enormous amount of animal protein has led to increased focus of studies on overcoming the adverse effects and stressful conditions of intensive production (Fraser, 2008; Korthals and Thompson, 2008).

Disease-free and stress-resistant calves are the basis of good production (Lensink et al., 2001). Chemotherapy and/or antibiotics were the most prevalent ways of dealing with stresses and diseases, however, with increasing apprehension about the consequences of the chronic use such as the development of resistant pathogen strains, accumulation of toxic residues, suppression of immune system and environmental risks, their use in many countries has been banned (Papatsiros et al., 2013). Eco-friendly natural strategies and/or functional feed additives such as fermentation, vaccines, and pro-, pre-, synbiotics, have been in great demand in the livestock sector (Musa et al., 2009). Coenzyme Q10 (CoQ10) and Lcarnitine (L-Ca) are an ideal additives that labor as an antioxidant, regulator of immunity and metabolism (Ghanbarzadeh et al., 2013). Both CoQ10 and L-Ca are naturally present in mammals, plants and some bacteria's biological system but in insufficient quantities, especially under stressful conditions and therefore need to be obtained from an external sources (Hernández-Camacho et al., 2018).

CoQ10 or ubiquinone, a hydrophobic molecule (Nepal et al., 2010), which occur in the mitochondrial inner membrane where function a significant part in the electron transport chain (ETC) and generates ATP (Shukla and Dubey, 2018). CoQ10 is an antioxidant and free radical eliminator and considered as a supervitamin (vitamin Q) that helps in the protection of DNA, cells membrane lipids and proteins from the 
hazards of the oxidative damage, assists regenerating of vitamin $\mathrm{E}$ and reliefs healthy energy levels (Bentinger et al., 2007; Linnane et al., 2007). The addition of CoQ10 aids to improve human and animal health in the case of many diseases such as obesity, diabetes, heart disease, muscle atrophy, aging, cancer, Alzheimer's disease, etc. (Adarsh et al., 2008; Prakash et al., 2010; Roffe et al., 2004; Sohet et al., 2009; Varela-López et al., 2016). Also, in vitro results indicate its anti-inflammatory role (Schmelzer et al., 2009).

Carnitine is produced naturally in the body from the amino acids lysine and methionine and the form of L-carnitine ( $\mathrm{L}-\mathrm{Ca})$ is considered a biologically active substance. Its vital role is an essential co-factor in transporting long-chain fatty acids to the inner membrane of mitochondria (lipids metabolism) and thus in energy production as well as improve neuronal metabolism which helps in the treatment of certain diseases such as Alzheimer's, obesity, diabetes and heart disease (Bloomer et al., 2009) . Due to the multiple benefits of CoQ10 and L-Ca, the potential therapeutic advantages and the ease of synthesis, whether by biological or chemical methods, have made it one of the special substances of high demand in the market along with other compounds such as alpha lipoic acid, vitamin C and vitamin E (Golbidi et al., 2011; Shukla and Dubey, 2018).

This study was designed to evaluate the effect of CoQ10 and L-Ca on the growth rate and health status of Egyptian buffalo calves.

\section{MATERIALS AND METHODS}

\section{Animals and experimental design:}

This study was performed at Animal Production Research Gemmieza station, Animal Production Research Institute, Agricultural Research Center, Ministry of Agriculture, Egypt. Fifteen Egyptian buffalo calves with $36.13 \pm 0.86 \mathrm{Kg}$ live body weight (LBW) were allocated into three groups, 5 animals each and were individually placed in a separate pen. Calves in the first group received no treatment and served as a control group (Ctrl). The calves in the second and third groups received $40 \mathrm{mg} \mathrm{L}-\mathrm{Carnitine}(\mathrm{L}-\mathrm{Ca}) / \mathrm{kg} \mathrm{LBW}$ and $10 \mathrm{mg}$ coenzyme Q10 (CoQ10)/kg LBW, respectively as daily oral administration from the fourth day to 105 days of age (weaning age).

\section{Feeding system:}

Animals were separately fed twice daily $(6: 00$ and 18:00 h) at the rate of 10\% of LBW on dam colostrum for the first three days (with no treatments) and whole cow milk until weaning with the gradual use of starter feed form day 15 after birth (Berseem hay, $\mathrm{BH} 3^{\text {rd }}$ cut and rice straw at free choice). Calves were given a free access to feeds and clean water during the experimental period.

\section{Growth performance:}

Animal's weights were recorded at birth and then measured at 30, 60, 90 and 105 days of age (weaning age) before serving the morning meal. The growth parameters were calculated according to the following formulae:

$$
\begin{gathered}
\text { Weight Gain }(\mathrm{WG}, \mathrm{Kg})=\mathrm{W}_{\mathrm{T}}-\mathrm{W}_{0} \\
\text { Average Daily Gain }(\mathrm{ADG}, \mathrm{Kg} / \text { day })=\frac{\mathrm{W}_{\mathrm{T}}-\mathrm{W}_{0}}{\mathrm{~T}}
\end{gathered}
$$

Where:

$\mathrm{W}_{\mathrm{T}}=$ body weight at a specific time; $\mathrm{W}_{0}=$ birth body weight; $\mathrm{T}=$ the trial period in days $(\mathrm{d})$.

\section{Blood sampling:}

Blood was sampled after 2 hour of feeding from all calves at the end of the experimental period by jugular venipuncture using sterile syringes with or without anticoagulant (heparin) and samples were centrifuged undercooling $\left(4^{\circ} \mathrm{C}\right)$ at a speed of $3000 \mathrm{rpm}$ for 10 minutes to obtain plasma and serum, respectively. Both of plasma and serum samples were kept at $-20^{\circ} \mathrm{C}$ until analysis. Blood hematological parameters [red blood cells (RBCs), white blood cells (WBCs), packed cell volume (PCV \%), and haemoglobin $(\mathrm{Hb})$ ] and biochemical contents [glucose, total protein, total lipids, cholesterol, triglycerides, 
alanine transaminase (ALT), aspartate transaminase (AST), and alkaline phosphatase (ALP)] were measured using Semi-automatic analyzer (Model 2000 Evolution, EMEG) for clinical chemistry and hematology tests using Bayer Diagnostics Reagents strips following the manufactory guidelines. The concentration of triiodothyronine (T3) and thyroxin (T4) in blood serum were measured using radioimmunoassay (RIA) commercial kits (Coat-A-Count $®-T K T 31)$ by Automatic Mini-Gamma Counter (LKB-1275). Immunoglobulin $\mathrm{G}$ and $\mathrm{M}$ concentrations in serum samples were determined with the quantitative ELISA (Bovine IgG and IgM, ELISA Quantitative kit, Bethyl laboratories, UK).

\section{Non-specific immune responses:}

Serum lysozyme activity (LYZ) was assessed spectrophotometrically at $450 \mathrm{~nm}$ with 96 -well microplate turbidimetric assay as described by Lygren et al. (1999). Bactericidal activity (BA) of serum was diagnosed spectrophotometrically at $570 \mathrm{~nm}$ according to the modified methods of Gallage et al. (2016) as described by Wang et al. 2018).

\section{Antioxidant potential assessment:}

Enzymes in serum samples were measured according to the method of Paoletti and Mocali (1990) (superoxide dismutase SOD) and Aebi (1984) (catalase CAT).

\section{Statistical analysis:}

Data were processed with the SPSS analysis program (SPSS version 15 for Windows) using one-way analysis of variance (ANOVA) and expressed as mean $\pm \mathrm{SE}$ of five replicates. To detect significance and to compare the means of treatments, Duncan multiple range tests were performed at $P<0.05$ level (Duncan, 1955).

\section{RESULTS AND DISCUSSION}

\section{Growth characteristics:}

Egyptian buffalo calves' growth during the trial period is shown in Table (1). From the age of 60 days until weaning, significant differences in weight were observed between treatments and CoQ10and L-Ca treatments gave the highest body weights and average daily gain (ADG) compared to the control at weaning.

Table (1): Body weight gain of Egyptian buffalo calves during the experimental period.

\begin{tabular}{|c|c|c|c|c|}
\hline \multirow{2}{*}{ Item } & \multicolumn{3}{|c|}{ Treatment } & \multirow{2}{*}{$P$-Value } \\
\hline & Ctrl & $\mathrm{L}-\mathrm{Ca}$ & CoQ10 & \\
\hline \multicolumn{5}{|c|}{ Body weight (BW, Kg): } \\
\hline Birth (BW0) & $35.80 \pm 1.07$ & $36.20 \pm 1.36$ & $36.40 \pm 2.16$ & 0.895 \\
\hline $30 \mathrm{~d}$ & $46.20 \pm 1.86$ & $49.80 \pm 2.89$ & $50.20 \pm 2.42$ & 0.782 \\
\hline $60 \mathrm{~d}$ & $63.00 \pm 2.12^{b}$ & $68.80 \pm 1.63^{\mathrm{ab}}$ & $69.80 \pm 2.15^{\mathrm{a}}$ & 0.045 \\
\hline $90 \mathrm{~d}$ & $77.60 \pm 2.02^{b}$ & $86.60 \pm 1.36^{\mathrm{a}}$ & $89.40 \pm 2.38^{\mathrm{a}}$ & 0.038 \\
\hline $105 \mathrm{~d}$ (Weaning) & $91.00 \pm 2.92^{b}$ & $104.20 \pm 3.61^{\mathrm{a}}$ & $110.20 \pm 2.78^{\mathrm{a}}$ & 0.020 \\
\hline \multicolumn{5}{|c|}{ Average total gain $(\mathrm{Kg})$ : } \\
\hline Birth $-30 \mathrm{~d}$ & $10.40 \pm 1.08$ & $13.60 \pm 2.16$ & $13.80 \pm 0.97$ & 0.910 \\
\hline $30 d-60 d$ & $16.80 \pm .86$ & $19.00 \pm 1.67$ & $19.60 \pm 0.40$ & 0.784 \\
\hline $60 d-90 d$ & $14.60 \pm 0.40^{b}$ & $17.80 \pm 0.37^{\mathrm{a}}$ & $19.60 \pm 1.03^{\mathrm{a}}$ & 0.042 \\
\hline $90 \mathrm{~d}$-weaning & $13.40 \pm 1.50^{\mathrm{b}}$ & $17.60 \pm 2.32^{\mathrm{ab}}$ & $20.80 \pm 0.58^{a}$ & 0.016 \\
\hline Birth - weaning & $55.20 \pm 2.15^{b}$ & $68.00 \pm 2.35^{\mathrm{a}}$ & $73.80 \pm 1.16^{\mathrm{a}}$ & 0.012 \\
\hline \multicolumn{5}{|c|}{ Average daily gain (ADG, $\mathrm{Kg} / \mathrm{d}$ ): } \\
\hline Birth $-30 \mathrm{~d}$ & $0.347 \pm 0.04$ & $0.453 \pm 0.07$ & $0.46 \pm 0.03$ & 0.880 \\
\hline $30 d-60 d$ & $0.560 \pm 0.03$ & $0.634 \pm 0.06$ & $0.654 \pm 0.01$ & 0.721 \\
\hline $60 d-90 d$ & $0.487 \pm 0.01^{\mathrm{b}}$ & $0.593 \pm 0.01^{\mathrm{a}}$ & $0.653 \pm 0.03^{\mathrm{a}}$ & 0.039 \\
\hline $90 \mathrm{~d}$-weaning & $0.447 \pm 0.05^{b}$ & $0.587 \pm 0.08^{a b}$ & $0.693 \pm 0.02^{\mathrm{a}}$ & 0.022 \\
\hline Birth - weaning & $0.526 \pm 0.02^{b}$ & $0.648 \pm 0.02^{\mathrm{a}}$ & $0.703 \pm 0.01^{\mathrm{a}}$ & 0.017 \\
\hline
\end{tabular}


The results of calves' growth during the trial period showed an improvement with the addition of CoQ10 and L-Ca. The increase in growth may be due to improve utilization of feed due to the role of CoQ10 and L$\mathrm{Ca}$ in improving the condition of the intestine by modulating intestine microflora or anti-inflammatory properties (Fortin et al., 2009; Lee et al., 2016). Moreover, this improvement in growth may be due to the indirect effect of CoQ10 and L-Ca on vitamin E re-synthesis (Bentinger et al., 2007; Linnane et al., 2007). Furthermore, CoQ10 plays a pivot in the metabolism of protein, lipids, and carbohydrates (Shukla and Dubey, 2018). In addition, the positive impacts of CoQ10 and L-Ca treatments on insulin, glucagon and cortisol hormones support its role in improving the performance of animal (Butler et al., 2003; Ruggenenti et al., 2009) .

\section{Blood hematological and biochemical metrics:}

Table (2) represents the blood indices of Egyptian buffalo calves at the end of the trial period. Blood statuses of all experimental animals show no satisfactory cases and were within normal rates. The hematological indices of the treated groups showed no significant variation $(P>0.05)$. Meanwhile, the biochemical contents are varied significantly in terms of glucose, total lipids, T-Chol, triglyceride, ALT, AST, and ALP. The control group gave the highest values of glucose, total lipids, T-Chol, triglyceride, ALT, AST, and ALP compared to the other groups. Moreover, the CoQ10 group exhibited the highest significant $(p<0.05)$ contents of TP.

Blood status is an accurate indicator that reflects the health status of the animal as well as the response to stressors and external stimuli (Puppel and Kuczyńska, 2016). Overall, the value of the blood indices recorded in the present study is within the normal ranges. Glucose is an accurate evidence of the presence of stress conditions as it increase with stress and decreases in well-being (Chen et al., 2015; Garner et al., 2017). Interestingly, levels of glucose have been decreased in calves fed CoQ10 and L-Ca when compared with un-supplemented calves; this could be linked either to hypoglycemic hormone stimulation (insulin) or reduction in glucose absorption (Modi et al., 2006). Also, total lipids, cholesterol and triglyceride levels were decreased and this may due to the hypocholesterolemic impact of CoQ10 and L-Ca (Huang et al., 2013; Lee et al., 2016; Raeisi-Zeydabad et al., 2017). Conversely, the higher total protein (TP) contents observed in CoQ10 group may indicate an improvement in calves' health or could be a post-injury or infection adaptation response(Gerwick et al., 2002; Panigrahi et al., 2010). Also, the noticed alterations in the activities of liver metabolic enzymes (ALT, AST, and ALP) reported in the present study reflect the absence of CoQ10 and L-Ca toxicity.

Table (2): Hematological and biochemical blood indices of Egyptian buffalo calves fed experimental additives.

\begin{tabular}{|c|c|c|c|c|}
\hline \multirow{2}{*}{ Item } & \multicolumn{3}{|c|}{ Treatment } & \multirow{2}{*}{$P$-Value } \\
\hline & Ctrl & $\mathrm{L}-\mathrm{Ca}$ & CoQ10 & \\
\hline $\operatorname{RBCs}^{1}\left(10^{6} / \mu 1\right)$ & $7.19 \pm 0.40$ & $7.32 \pm 0.18$ & $8.06 \pm 0.61$ & 0.108 \\
\hline $\operatorname{WBCs}^{2}\left(10^{6} / \mu \mathrm{l}\right)$ & $9.47 \pm 0.50$ & $10.13 \pm 0.41$ & $10.88 \pm 0.62$ & 0.215 \\
\hline $\mathrm{PCV}^{3} \%$ & $31.42 \pm 0.88$ & $32.75 \pm 0.71$ & $33.20 \pm 0.62$ & 0.342 \\
\hline $\mathrm{Hb}^{4}(\mathrm{~g} / \mathrm{dl})$ & $10.68 \pm 0.55$ & $11.02 \pm 0.78$ & $12.01 \pm 0.59$ & 0.448 \\
\hline Glucose (mg/dl) & $101.04 \pm 2.06^{\mathrm{a}}$ & $81.56 \pm 2.32^{b}$ & $77.38 \pm 1.84^{\mathrm{b}}$ & 0.033 \\
\hline $\mathrm{TP}^{5}(\mathrm{~g} / \mathrm{dl})$ & $6.30 \pm 0.18^{c}$ & $7.94 \pm 0.15^{b}$ & $8.89 \pm 0.12^{\mathrm{a}}$ & 0.042 \\
\hline Total lipids (mg/dl) & $697.60 \pm 6.78^{\mathrm{a}}$ & $653.48 \pm 7.18^{\mathrm{b}}$ & $544.04 \pm 6.60^{\mathrm{c}}$ & 0.000 \\
\hline T-Chol ${ }^{6}(\mathrm{mg} / \mathrm{dl})$ & $102.74 \pm 2.02^{\mathrm{a}}$ & $92.58 \pm 1.47^{\mathrm{b}}$ & $77.95 \pm 1.68^{c}$ & 0.000 \\
\hline Triglyceride (mg/dl) & $56.03 \pm 0.76^{\mathrm{a}}$ & $51.89 \pm 0.63^{b}$ & $42.15 \pm 0.79^{c}$ & 0.030 \\
\hline $\mathrm{ALT}^{7}(\mathrm{IU} / \mathrm{l})$ & $13.64 \pm 0.29^{\mathrm{a}}$ & $10.90 \pm 0.25^{b}$ & $9.45 \pm 0.22^{c}$ & 0.027 \\
\hline $\mathrm{AST}^{8}(\mathrm{IU} / \mathrm{l})$ & $35.14 \pm 0.69^{\mathrm{a}}$ & $30.55 \pm 0.84^{b}$ & $26.86 \pm 0.62^{c}$ & 0.018 \\
\hline $\mathrm{ALP}^{9}(\mathrm{IU} / \mathrm{l})$ & $94.52 \pm 1.34^{\mathrm{a}}$ & $81.93 \pm 2.50^{\mathrm{c}}$ & $88.19 \pm 1.77^{\mathrm{b}}$ & 0.039 \\
\hline Creatinine (mg/dl) & $1.46 \pm 0.22$ & $1.24 \pm 0.26$ & $1.22 \pm 0.19$ & 0.384 \\
\hline Urea $(\mathrm{mg} / \mathrm{dl})$ & $19.18 \pm 0.60$ & $18.23 \pm 0.53$ & $18.20 \pm 0.49$ & 0.432 \\
\hline
\end{tabular}


Serum triiodothyronine (T3), Thyroxine (T4), and Immunoglobulin G and M concentrations at 105 day of age of calves were presented in Fig. (1). No differences were found between the experimental groups in blood IgG and IgM contents. The highest T3 and T4 values were observed in the control group followed by L-Ca group and the lowest values were seen in the CoQ10 group.
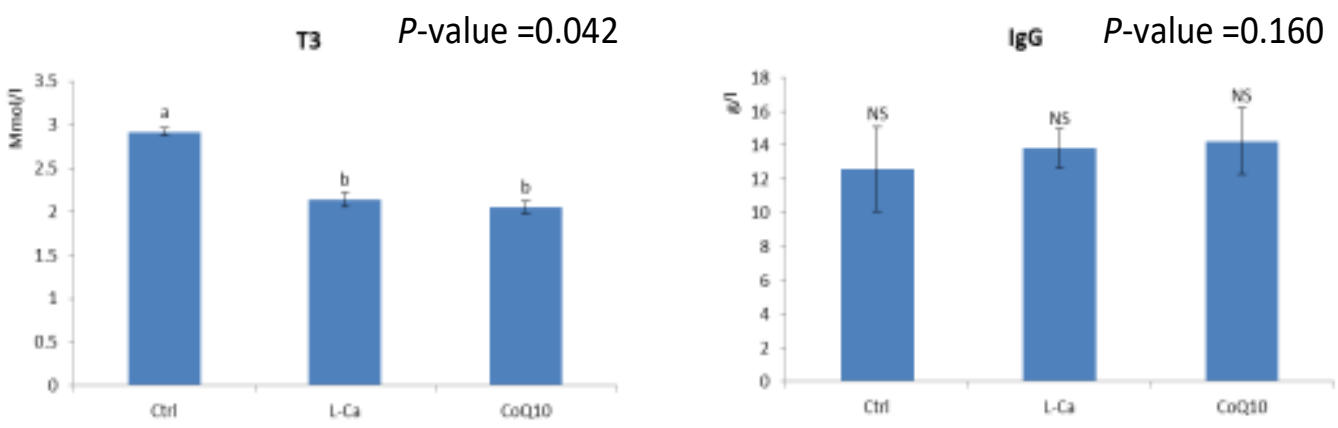

T4 $\quad P$-value $=0.031$

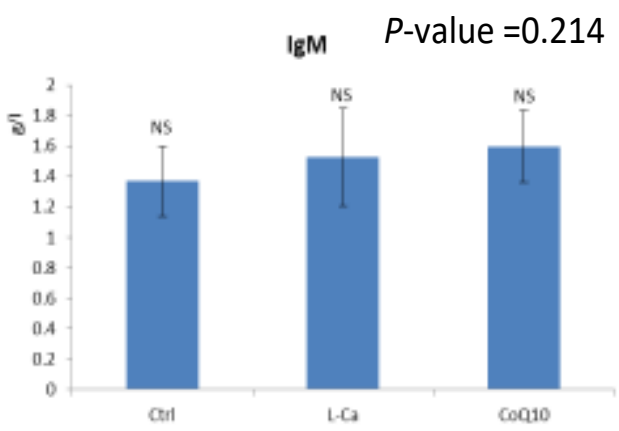

Fig. (1): Egyptian buffalo calves serum triiodothyronine (T3), Thyroxine (T4), and Immunoglobulin G and $M$ concentrations at 105 day of age.

\section{Non-specific immune responses:}

Serum lysozyme (LYZ) and bactericidal activities (BA) of Egyptian buffalo calves are presented in Fig. (2). The lowest values of LYZ and BA activities were recorded in the control group and the highest values were observed in group supplemented with CoQ10.
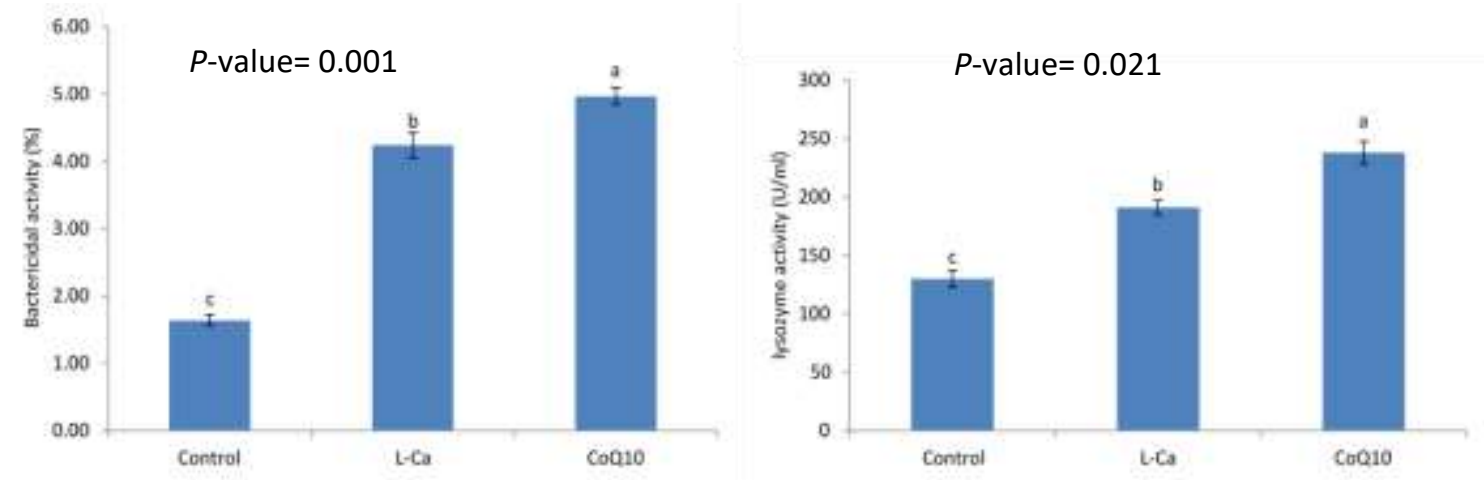

Fig. (2): Egyptian buffalo calves' serum bactericidal and lysozyme activities. 
Immune responses in animals can be altered by feed additives treatments by stimulating immune cells directly or indirectly through metabolic, neurological, or endocrine pathways (Selvaraj, 2012). Phagocytosis is one of the main defense mechanisms in animals which is used in the activities of lysozyme and antimicrobes (bactericidal activity)(Janeway et al., 2001; Karavitis and Kovacs, 2011). The activity of lysozyme used to assess the ability of the immune system in different animals (Cecchini et al., 2000). Bactericidal activity (BA) serves as a main tool of the host to withstand pathogens (Kawakami et al., 2000).CoQ10's result in raising body immunity can be attributed to improved body energy, enhanced mitochondrial respiration, or / and maximized vitamin E level (Feher et al., 2007; Raeisi-Zeydabad et al., 2017).

\section{Antioxidant potential assessment:}

Data on serum SOD and CA contents are presented in Fig. 3. The highest SOD and CA contents were recorded in groups supplemented with CoQ10 and L-Ca compared to the control group.
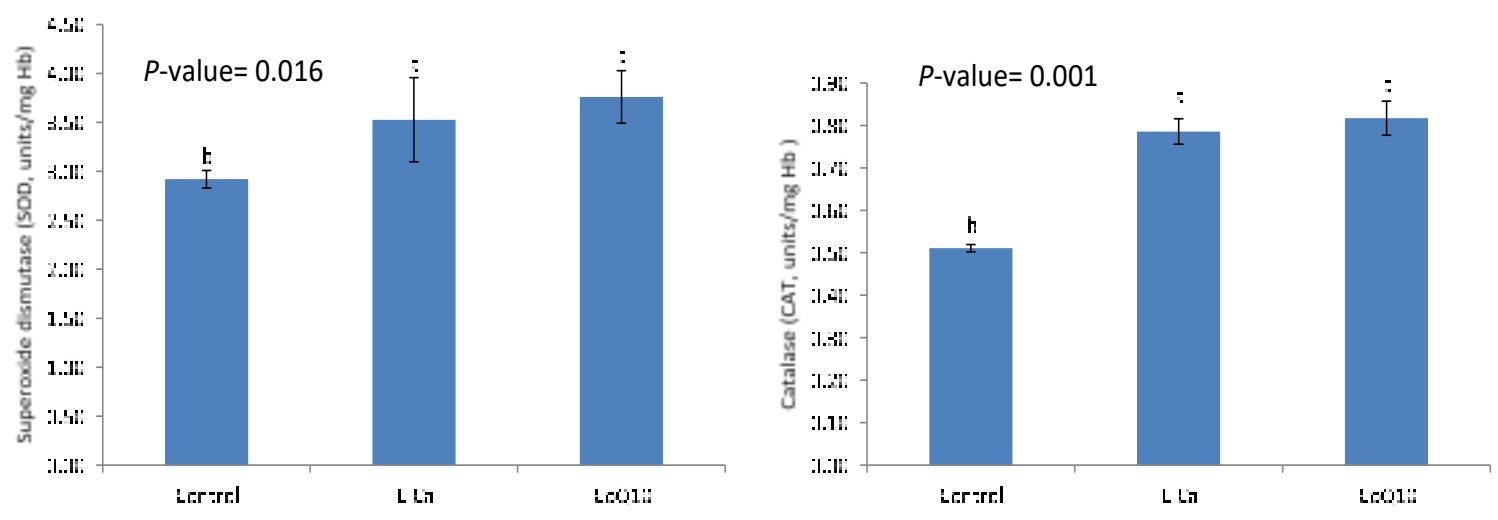

Fig. (3): Egyptian buffalo calves serum superoxide dismutase (SOD) and catalase (CAT) contents at 105 day of age.

There is a strong correlation between oxidative state and the immunity (Alhidary et al., 2016; Tomasi et $a l ., 2018)$. Oxidative stress increases as a result of an imbalance between the production and disposal of reactive oxygen species (ROS) (Castro and Tafalla, 2015; Sharbidre et al., 2011). SOD and CAT as major part of the antioxidant defense line play vital roles in removing excessive ROS, sustaining the homeostasis of the cell (Aruoma, 1998). SOD and CAT values were significantly higher in groups supplemented with CoQ10 and L-Ca compared with the control group emphasizing the antioxidant capacities of CoQ10 and LCa. CoQ10 is well known as a super-vitamin (vitamin Q) that exhibits potent antioxidant ability, free radical scavenger, helps regenerating of vitamin E, supports healthy energy levels, improves health in case of many disease (Varela-López et al., 2016). Furthermore, L-carnitine (L-Ca) exhibits potent antioxidant ability, free radical scavenger, helps in energies body, and the treatment of certain diseases (Bloomer et al., 2009).

In conclusion, CoQ10 or L-Ca supplements improve the growth, health being of Egyptian buffalo calves. CoQ10 is similar to L-Ca in its antioxidant capacity while CoQ10 outperforms L-Ca to boost immunity.

\section{ACKNOWLEDGMENT}

The author would like to thank all staff member of Animal production Department, Faculty of Agriculture, Tanta University, Egypt for supporting and supervising this research. We express our sincere gratitude to Animal Research station staff, Gemmieza Agricultural research center, Egypt for the facilities, equipment and technical support. 


\section{REFERENCES}

Aebi, H. (1984). Catalase in Vitro. Methods in Enzymology, 105:121-126.

Alhidary, I. A., M. M. Abdelrahman, R. Uallh Khan and R. M. Harron (2016). Antioxidant status and immune responses of growing camels supplemented a long-acting multi-trace minerals rumen bolus. Italian Journal of Animal Science, 15:343-349.

Anadón, A., M. Rosa Martínez-Larrañaga and M. Aranzazu Martínez (2006). Probiotics for animal nutrition in the European Union. Regulation and safety assessment. Regulatory Toxicology and Pharmacology, 45:91-95.

Aruoma, O. (1998). Free radicals, oxidative stress and antioxidants in human health and disease. Journal of the American Oil Chemists' Society, 75:199-212.

Bentinger, M., K. Brismar,and G. Dallner (2007). The antioxidant role of coenzyme Q. Mitochondrion, 7:S41-S50.

Bertoni, G., A. Minuti and E. Trevisi (2015). Immune system, inflammation and nutrition in dairy cattle. Animal Production Science, 55:943.

Bloomer, R. J., L. C. Tschume and W. A. Smith (2009). Glycine propionyl-L-carnitine modulates lipid peroxidation and nitric oxide in human subjects. International Journal for Vitamin and Nutrition Research, 79:131-141.

Bolt, S. L., N. K. Boyland, D. T. Mlynski, R. James and D. P. Croft (2017). Pair Housing of Dairy Calves and Age at Pairing: Effects on Weaning Stress, Health, Production and Social Networks. PLOS ONE 12:e0166926.

Butler, M. G., M. Dasouki, D. Bittel, S. Hunter, A. Naini and S. DiMauro (2003). Coenzyme Q10 levels in Prader-Willi syndrome: Comparison with obese and non-obese subjects. American Journal of Medical Genetics, 119A:168-171.

Castro, R., and C. Tafalla (2015). Overview of fish immunity. Pages 3-54 Mucosal Health in Aquaculture. Elsevier Inc.

Cecchini, S., G. Terova, G. Caricato and M. Saroglia (2000). Lysozyme activity in embryos and larvae of sea bass (Dicentrarchus labrax L.), spawned by broodstocks fed with vitamin C enriched diets. Bulletin of the European Association of Fish Pathologists, 20:120-124.

Chen, Y., R. Arsenault, S. Napper and P. Griebel (2015). Models and methods to investigate acute stress responses in cattle. Animals, 5:1268-1295.

Duncan, D. B. (1955). Multiple Range and Multiple F Tests. Biometrics 11:1-42.

Feher, J., E. Nemeth, V. Nagy, G. Lengyel and J. Feher (2007). The preventive role of coenzyme Q10 and other antioxidants in injuries caused by oxidative stress. Archives of Medical Science, 3:305-314.

Fortin, G., K. Yurchenko, C. Collette, M. Rubio, A.-C. Villani, A. Bitton, M. Sarfati and D. Franchimont (2009). L-carnitine, a diet component and organic cation transporter OCTN ligand, displays immunosuppressive properties and abrogates intestinal inflammation. Clinical \& Experimental Immunology, 156:161-171.

Fraser, D. (2008). Animal Welfare and the Intensification of Animal Production. Pages 167-189.

Gaggìa, F., P. Mattarelli and B. Biavati (2010). Probiotics and prebiotics in animal feeding for safe food production.

Gallage, S., T. Katagiri, M. Endo, K. Futami, M. Endo and M. Maita (2016). Influence of moderate hypoxia on vaccine efficacy against Vibrio anguillarum in Oreochromis niloticus (Nile tilapia). Fish and Shellfish Immunology, 51:271-281.

Garner, J. B., M. Douglas, S. R. O. Williams, W. J. Wales, L. C. Marett, K. DiGiacomo, B. J. Leury and B. J. Hayes (2017). Responses of dairy cows to short-term heat stress in controlled-climate chambers. Animal Production Science, 57:1233. 
Gerwick, L., R. Steinhauer, S. Lapatra, T. Sandell, J. Ortuno, N. Hajiseyedjavadi and C. J. Bayne (2002). The acute phase response of rainbow trout (Oncorhynchus mykiss) plasma proteins to viral, bacterial and fungal inflammatory agents. Fish and Shellfish Immunology, 12:229-242.

Ghanbarzadeh, S., A. Garjani, M. Ziaee and A. Khorrami (2013). CoQ10 and L-Carnitine attenuate the effect of high LDL and oxidized LDL on spermatogenesis in male rats. Drug Research, 64:510-515.

Golbidi, S., S. A. Ebadi,and I. Laher (2011). Antioxidants in the treatment of diabetes. Current diabetes reviews, 7:106-25.

Hernández-Camacho, J. D., M. Bernier, G. López-Lluch and P. Navas (2018). Coenzyme Q10 Supplementation in Aging and Disease. Frontiers in Physiology, 9:44.

Huang, H., L. Song, H. Zhang, H. Zhang, J. Zhang and W. Zhao (2013). Influence of L-Carnitine Supplementation on Serum Lipid Profile in Hemodialysis Patients: A Systematic Review and MetaAnalysis. Kidney and Blood Pressure Research, 38:31-41.

Huang, R.-L., Z.-Y. Deng, C. Yang, Y.-L. Yin, M. Y. Xie, G.-Y. Wu, T.-J. Li, L.-L. Li, Z.-R. Tang, P. Kang, Z.-P. Hou, D. Deng, H. Xiang, X. F. Kong and Y.-M. Guo (2007). Dietary oligochitosan supplementation enhances immune status of broilers. Journal of the Science of Food and Agriculture, 87:153-159.

Izgüt-Uysal, V. N., A. Ağaç, I. Karadoğan and N. Derin (2003). Effects of L-carnitine on neutrophil functions in aged rats. Mechanisms of Ageing and Development, 124:341-347.

Janeway, C. A. J., P. Travers, M. Walport and M. J. Shlomchik (2001). he front line of host defense. Page Immunobiology: The Immune System in Health and Disease. Fifth edition. Garland Science, New York.

Karavitis, J. and E. J. Kovacs (2011). Macrophage phagocytosis: effects of environmental pollutants, alcohol, cigarette smoke, and other external factors. Journal of Leukocyte Biology, 90:1065-1078.

Kawakami, H., H. Yamashita and M. Sakai (2000). Comparative sensitivity of yellowtail Seriola quinqueradiata and goldstriped amberjack S. aureovittata to Photobacterium damsela subsp. piscicida. Journal of the World Aquaculture Society, 31:213-217.

Klasing, K. C. (2007). Nutrition and the immune system. British Poultry Science, 48:525-537.

Korthals, M. and P. B. Thompson (2008). The Ethics of Intensification. Page (M. Korthals and P. B. Thompson, Eds.). Springer Netherlands.

de Lange, C. F. M., J. Pluske, J. Gong and C. M. Nyachoti (2010). Strategic use of feed ingredients and feed additives to stimulate gut health and development in young pigs. Livestock Science, 134:124-134.

Lee, B. J., J. S. Lin, Y. C. Lin, and P. T. Lin (2016). Effects of L-carnitine supplementation on lipid profiles in patients with coronary artery disease. Lipids in Health and Disease 15.

Lensink, B. J., I. Veissier and L. Florand (2001). The farmers' influence on calves' behaviour, health and production of a veal unit. Animal Science, 72:105-116.

Linnane, A. W., M. Kios and L. Vitetta (2007). Coenzyme Q10 - Its role as a prooxidant in the formation of superoxide anion/hydrogen peroxide and the regulation of the metabolome. Mitochondrion, 7:S51-S61.

Lygren, B., H. Sveier, B. Hjeltness and R. Waagbo (1999). Examination of the immunomodulatory properties and the effect on disease resistance of dietary bovine lactoferrin and vitamin $\mathrm{C}$ fed to atlantic salmon (Salmo salar) for a short-term period. Fish and Shellfish Immunology, 9:95-107.

Modi, K., D. D. Santani, R. K. Goyal and P. A. Bhatt (2006). Effect of coenzyme Q10 on catalase activity and other antioxidant parameters in streptozotocin-induced diabetic rats. Biological trace element research, 109:25-34.

Musa, H. H., S. L. Wu, C. H. Zhu, H. I. Seri and G. Q. Zhu (2009). The potential benefits of probiotics in animal production and health. Journal of Animal and Veterinary Advances, 8:313-321.

Nepal, P. R., H.-K. Han and H.-K. Choi (2010). Enhancement of solubility and dissolution of Coenzyme Q10 using solid dispersion formulation. International Journal of Pharmaceutics, 383:147-153.

Panigrahi, A., V. Kiron, S. Satoh and T. Watanabe (2010). Probiotic bacteria Lactobacillus rhamnosus influences the blood profile in rainbow trout Oncorhynchus mykiss (Walbaum). Fish Physiology and 


\section{Egyptian J. Nutrition and Feeds (2020)}

Biochemistry, 36:969-977.

Paoletti, F. and A. Mocali (1990). Determination of superoxide dismutase activity by purely chemical system based on NAD(P)H oxidation. Methods in enzymology, 186:209-20.

Papaioannou, D., P. D. Katsoulos, N. Panousis,and H. Karatzias (2005). The role of natural and synthetic zeolites as feed additives on the prevention and/or the treatment of certain farm animal diseases: A review. Microporous and Mesoporous Materials, 84:161-170.

Papatsiros, V. G., P. D. Katsoulos, K. C. Koutoulis, M. Karatzia, A. Dedousi,and G. Christodoulopoulos (2013), November. Alternatives to antibiotics for farm animals.

Puppel, K. and B. Kuczyńska (2016). Metabolic profiles of cow’s blood; a review. Journal of the Science of Food and Agriculture, 96:4321-4328.

Raeisi-Zeydabad, S., R. Mirmahmoudi, O. Esmaeilipour and M. Mazhari (2017). Effects of Coenzyme Q10 and Vitamin $\mathrm{C}$ on Growth Performance and Blood Components in Broiler Chickens under Heat Stress. Poultry Science Journal, 6604:145-152.

Rehman, Z. ur, N. Chand and R. U. Khan (2017). The effect of vitamin E, 1-carnitine, and ginger on production traits, immune response, and antioxidant status in two broiler strains exposed to chronic heat stress. Environmental Science and Pollution Research, 24:26851-26857.

Ruggenenti, P., D. Cattaneo, G. Loriga, F. Ledda, N. Motterlini, G. Gherardi, S. Orisio and G. Remuzzi (2009). Ameliorating hypertension and insulin resistance in subjects at increased cardiovascular risk: effects of acetyl-L-carnitine therapy. Hypertension (Dallas, Tex. : 1979) 54:567-74.

Schmelzer, C., G. Lorenz, G. Rimbach and F. Döring (2009). In Vitro effects of the reduced form of coenzyme Q10 on secretion levels of TNF- $\alpha$ and chemokines in response to LPS in the human monocytic cell line THP-1. Journal of Clinical Biochemistry and Nutrition, 44:62-66.

Selvaraj, R. K. (2012). Maximum immunity effectors: Mechanisms and animal performance limitations,. The Journal of Applied Poultry Research 21:185-192.

Sharbidre, A. A., V. Metkari and P. Patode (2011). Effect of methyl parathion and chlorpyrifos on certain biomarkers in various tissues of guppy fish, Poecilia reticulata. Pesticide Biochemistry and Physiology, 101:132-141.

Shukla, S. and K. K. Dubey (2018). CoQ10 a super-vitamin: review on application and biosynthesis. 3 Biotech., 8:249.

Sohet, F. M., A. M. Neyrinck, B. D. Pachikian, F. C. de Backer, L. B. Bindels, P. Niklowitz, T. Menke, P. D. Cani,and N. M. Delzenne (2009). Coenzyme Q10 supplementation lowers hepatic oxidative stress and inflammation associated with diet-induced obesity in mice. Biochemical Pharmacology, 78:1391-1400.

Storelli, G., A. Defaye, B. Erkosar, P. Hols, J. Royet and F. Leulier (2011). Lactobacillus plantarum promotes drosophila systemic growth by modulating hormonal signals through TOR-dependent nutrient sensing. Cell Metabolism, 14:403-414.

Tomasi, T., A. Volpato, W. A. B. Pereira, L. H. Debastiani, N. B. Bottari, V. M. Morsch, M. R. C. Schetinger, M. L. R. Leal, G. Machado and A. S. Da Silva (2018). Metaphylactic effect of minerals on the immune response, biochemical variables and antioxidant status of newborn calves. Journal of Animal Physiology and Animal Nutrition, 102:819-824.

Varela-López, A., F. Giampieri, M. Battino, and J. Quiles (2016). Coenzyme Q and Its Role in the Dietary Therapy against Aging. Molecules, 21:373.

Wang, J., R. Z. He, G. L. Lu, H. L. Luo, D. Q. Lu and A. X. Li (2018). Vaccine-induced antibody level as the parameter of the influence of environmental salinity on vaccine efficacy in Nile tilapia. Fish and Shellfish Immunology, 82:522-530.

Wang, X., H. Liu, J. Chen, Y. Li and S. Qu (2015). Multiple factors related to the secretion of glucagon-like peptide-1. Hindawi Publishing Corporation. 
تأثير مساعد الانزيم Q10 والكارنتين علي أداء النمو وصحة الدم وحالة مضادات الأكسدة والاستجابة المناعية لعجول الجاموس المصري حديثة الولادة

أحمد عبد الونيس جبر

قسم الإنتاج الحيواني - كلية النزراعة - جامعة طنطا ـــر.

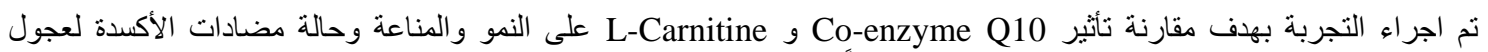

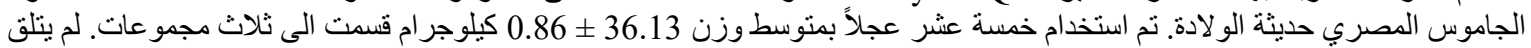

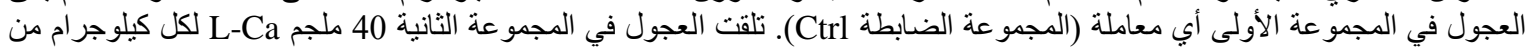

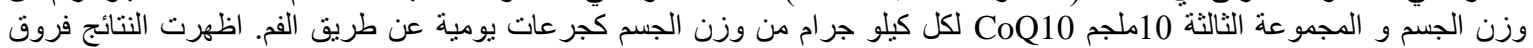

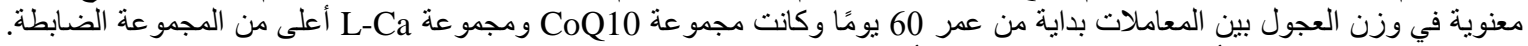

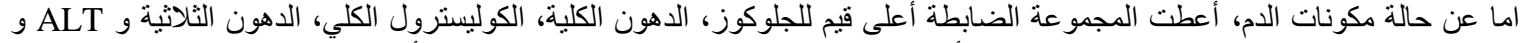

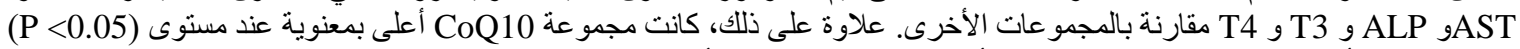

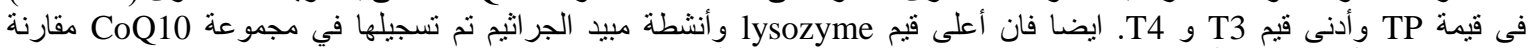

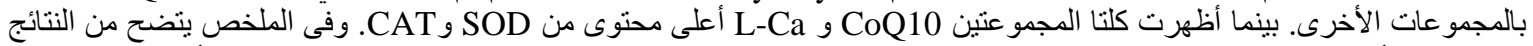

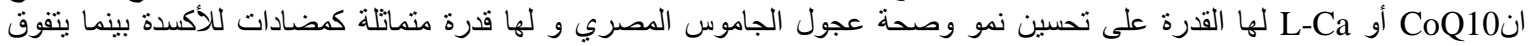
على CoQ10 